https://doi.org/10.34142/23129387.2019.61.04

UDC 37.013.73: 392.3

ORCID 0000-0001-9339-7737

ORCID 0000-0002-3265-2666

\title{
LEGO CONSTRUCTION SETS AS A MEANS OF PRIMARY SCHOOLCHILDREN'S CRITICAL THINKING DEVELOPMENT
}

\author{
Iryna I. Dorozhko ${ }^{1 A B C D}$, Ludmila V. Turishcheva ${ }^{\text {IABCD }}$
}

H.S.Skovoroda Kharkiv National Pedagogical University,29, Alchevskyh str., Kharkiv, Ukraine,

1Head of of the Department of Philosophical and Psychological Anthropology

E-mail: psychotherapy16@gmail.com

2 Associate Professor of the Department of Philosophical and Psychological Anthropology

E-mail: tyrludvas@gmal.com

Aim: To evaluate the level of development of critical thinking elements in the process of working with a constructor in elementary school students. The main tasks are:1) to analyze the concept of "critical thinking" in the works of researchers; 2) to establish the main characteristics of critical thinking and its ability; 3) to identify the impact of "LEGO" on the development of critical thinking in younger students.

Research Methods. Comparative analysis of sources of scientific pedagogical literature, interpretation, formulation of conclusions. The results are processed mathematically and presented in the format of comparative tables.

Results. The article presents the analysis of psychological and pedagogical research. The concept of "critical thinking" is analyzed, its signs are shown. The peculiarities of critical thinking of the younger student are formulated, the educational possibilities of the designer are considered. The peculiarities of the development of critical thinking in younger students in the process of tasks with the designer "LEGO" are revealed. LEGO classes provide opportunities for diverse development of students and the formation of the most important competences reflected in the concept of the New Ukrainian School. critical thinking is formed and developed when processing information, solving problems, problems, 
assessing the situation, choosing rational ways of activity. It is in the process of working with the designer, first of all, is the processing of information, assessment of the situation. Therefore, this process can be considered a condition for the development of critical thinking. The study contains empirical results obtained during the work with the experimental data. In the process of completing the tasks, the following indicators are observed: the ability to put ideas into words; ability to find cause and effect; the ability to combine several ideas into one, to create a new idea.

Conclusions. School practice requires the development of new technologies for the formation of students' critical thinking in the learning process, the use of a variety of different pedagogical techniques that encourage students to creative activity, create conditions for them to become aware of the educational material, generalization of the acquired knowledge. Tasks with "LEGO" should be used in working with younger students to develop critical thinking.

Keywords: critical thinking, signs of critical thinking, junior high school student.

\section{Конструктори «LEGO» як засіб розвитку критичного мислення молодших школярів}

Ірина І. Дорожко ${ }^{1}$, Людмила В. Туріщева ${ }^{2}$,

1 - завідувач кафедри філософсько-психологічної антропології,

2 - дочент кафедри філософсько-психологічної антропології,

Харківський національний педагогічний університет імені

Г.С. Сковороди, м. Харків, Україна

Мета: оцінити рівень розвитку у молодших школярів елементів критичного мислення у прочесі роботи з конструктором.

Основними завданнями є:

1) проаналізувати склад поняття «критичне мислення» $y$ роботах дослідників; 2) встановити основні характеристики критичного мислення та здатності до нього; 3) виявити вплив «LEGO» на розвиток критичного мислення у молодших школярів.

Методи: Порівняльний аналіз джерел наукової педагогічної літератури, інтерпретація, формулювання висновків. Результати обробляються математично і представлені у форматі порівняльних таблиць. 
Результати. У статті представлено аналіз психологопедагогічних досліджень. Проаналізовано поняття «критичне мислення», показано його ознаки. Сформульовано особливості критичного мислення молодшого школяра, розглянуто навчальні можливості конструктора. Виявлено особливості розвитку критичного мислення у молодших школярів у процесі виконання завдань з конструктором «LEGO».

Заняття з «LEGO» надають можливості різнобічного розвитку учнів $i$ формування найважливіших компетенщій, відображених $y$ концепиії Нової украӥнської школи. критичне мислення формується та розвивається під час опрачювання інформації, розв'язання задач, проблем, оцінки ситуачії, вибору раціональних способів діяльності. Саме, y прочесі роботи з конструктором, у першу чергу, здійснюється опрачювання інформації, оцінка ситуації. Тому, цей прочес можна вважати умовою розвитку критичного мислення.

Дослідження містить емпіричні результати, які отримано у ході роботи з експериментальними даними. У процесі виконання завдань зафіксовано наступні показники: здатність викласти ідеї свойми словами; вміння знайти причини та наслідки; вміння поєднати кілька ідей в одну, створити нову ідею.

Висновки. Шкільна практика потребує розробки нових технологій формування критичного мислення школярів у прочесі навчання, використання сукупності різноманітних педагогічних прийомів, які спонукають учнів до творчої активності, створюють умови для усвідомлення ними навчального матеріалу, узагальнення отриманих знань.

Завдання 3 «LEGO» необхідно використовувати в роботі 3 молодщими школярами для розвитку критичного мислення.

Ключові слова: критичне мислення, ознаки критичного мислення, молодиий школяр.

Introduction. The Ukrainian school nowadays is facing the task of educating a person who is capable of independent thinking, making daring non-standard decisions, generating original ideas. The main teacher's task is to form a child's ability to identify the most important points, to analyze, to systematize information, make conclusions, that is to develop critical thinking.

Critical thinking is not necessarily completely original. We have the right to accept another person's idea or belief as our own. We are 
often, even, pleased to agree with someone else's opinion because it confirms our point of view (Facione, 1990). Independence is thus the first and, perhaps, the most important characteristic of critical thinking. It is impossible to attribute critical thinking to the traditional study of facts. However, a teacher's job is not restricted to teaching the process of critical thinking: we teach our students to understand the most complex concepts and to hold a variety of information in memory.

It is necessary for students to have enough freedom in order to think and to solve the most difficult issues independently. One is capable of critical thinking at any age. Even first-year school children have accumulated enough life experience and knowledge to do it. It is through critical thinking that the traditional process of knowledge acquisition finds its individuality and becomes conscious, continuous and productive. Critical thinking can be developed at different lessons, while doing different types of educational activities. We think that doing tasks using construction sets is one of the means of teaching critical thinking.

The scientists studied critical thinking in various aspects: the role of criticality in the independent creative activity was revealed by V.Bibler, L.Hryhorovych, V.Razumovskyi, V.Shubynskyi and others; in choosing approaches to problem solving - by A.Bairamov, B.Zeiharnyk, S.Korol, H.Lypkina, Ye.Polat, S.Rubinshtein, Yu.Samarin, O.Tiahlo and others. The analysis of psychological and pedagogical literature makes it possible to conclude that critical thinking was primarily the subject of the research of the scientific world of psychology.

Psychological researches do not have a single point of view on the definition of the concept of "critical thinking". Thus, M. Clarin believes that critical thinking is rational, reflective thinking that is aimed at deciding what should be believed or what actions should be taken. D. Halpern in her works points out that this kind of thinking involves the use of cognitive techniques and strategies which increase the possibility of achieving the desired outcome. 
The purpose of the research is to evaluate the level of development of elements of primary schoolchildren's critical thinking in the process of working with LEGO construction sets.

The main tasks are: works;

1) to analyze the concept of "critical thinking" in researchers'

2) to establish the main characteristics of critical thinking and the ability to use it;

3) to identify the impact of LEGO on primary schoolchildren's critical thinking development.

The methods of the research are a comparative analysis of the sources of scientific pedagogical literature, interpretation, making conclusions. The study involved 30 second-grade children of school № 8 in Kharkiv.

In the author's methodology of critical thinking development, we proceed from the position of well-known researchers D. Cluster and J. Dewey (Cluster et al., 2001). It is noted that critical thinking begins with posing questions and clarifying the problems that need to be solved. Focusing on the problems stimulates students' natural curiosity, encourages them to think critically.

Results. Critical thinking is a part of the general structure of thinking in the process of cognition and is a higher order thinking skill. Each successive level includes the previous one: general thinking is a general process of information processing; thinking on the subject is the process of processing information on a particular subject using scientific research methods which is enriched with subject matter knowledge and methodological knowledge; critical thinking is a process of controlling the progress of general thinking and thinking on the subject, and improving them.

It is known that critical thinking is formed and developed when processing information, solving problems and tasks, evaluating a situation, choosing rational ways of doing things. It is in the process of working with the construction set, first of all, that information processing is done, and the situation is evaluated. Therefore, this process can be considered a condition for critical thinking development. 
We believe that one of the means of primary schoolchildren's critical thinking development is using the tasks with LEGO construction set in the educational process.

The methods of teaching using LEGO construction sets are diverse. The educators emphasize that due to its content, form of organization and high level of outcome, using LEGO in the classroom contributes to the formation of the ability to analyze, compare and distinguish features of characters and events. This affects the development of attention, observation skills, memory, spatial ideas, and imagination.

With the help of LEGO construction sets the following tasks of education are solved: teaching the correct and fast orientation in some area; the development of fine motor skills, the stimulation of general speech development and mental abilities, obtaining and expanding mathematical knowledge; expansion of ideas about the outside world, the development of attention, ability to concentrate, memory, thinking; teaching imagination and creative thinking; being able to mentally divide the subject into its constituent parts and to assemble into one whole; learning how to communicate, respect for one's own and other people's work.

Classes during which LEGO construction sets are used provide opportunities for pupils' all-round development and the formation of the most important competencies described in the concept of the New Ukrainian School. They include experimental research skills: hypothesis formation, finding a solution to the problem, doing observation and measurement, establishing causal relationships, evaluating the influence of individual factors, processing and analyzing the results; subject skills: the principles of modelling, construction and design; understanding cross-curricular relationships; the development of creative, imaginative, spatial, logical, constructive thinking, etc.

In order to develop primary schoolchildren's critical thinking, we used the following tasks.

1. "Forecasting by Illustration"

A teacher shows an illustration on some topic. Children have to make their own assumptions on the topic. Then the teacher asks the 
children to create a story with LEGO to continue what is happening on the illustration.

2. "An Illustration Made after Receiving Information" or "Live Drawings".

Students form their associations based on the content of the poem or tale which were read or the stories which were heard on the previous excursion.

3. "Creating a Story Using Keywords"

The teacher offers key words and word combinations such as: "a ship, a captain, an anchor, pirates, a storm, an island, appearance of a new ship, crew rescue". Then the children need to crate a story using the construction set. While working with the construction set, children make up a story using the plot.

In the process of completing the tasks, the following criteria were recorded: 1) the ability to repeat something essential in the form in which it was presented and heard; 2) the ability to express ideas in schoolchildren's own words or using some other method; 3 ) the ability to see the possibility of applying a particular idea to another situation; 4) the ability to find causes and effect; 5) the ability to combine several ideas into one, to create a new idea.

The obtained results are presented in Tables 1, 2 .

Table 1

Second-graders'abilities to work with LEGO construction sets (\%)

\begin{tabular}{|l|c|c|c|c|}
\hline \multirow{2}{*}{ Evaluation criteria } & Levels of Achievement in Working with LEGO \\
\cline { 2 - 5 } & Beginners & Intermediatelevel & $\begin{array}{c}\text { Sufficient } \\
\text { level }\end{array}$ & Highlevel \\
\hline $\begin{array}{l}\text { the ability to repeat } \\
\text { something significant in } \\
\text { the form in which it was } \\
\text { presented and heard }\end{array}$ & $35 \%$ & $40 \%$ & $20 \%$ & $5 \%$ \\
$\begin{array}{l}\text { the ability to express ideas } \\
\text { in schoolchildren's own } \\
\text { words or using some other } \\
\text { method }\end{array}$ & $30 \%$ & $45 \%$ & $25 \%$ & - \\
\hline $\begin{array}{l}\text { the ability to see the } \\
\text { possibility of applying a } \\
\text { particular idea another } \\
\text { situation }\end{array}$ & $45 \%$ & $45 \%$ & $10 \%$ & - \\
\hline $\begin{array}{l}\text { the ability to combine } \\
\text { several ideas into one, to } \\
\text { create a new idea or to get } \\
\text { an idea from one } \\
\text { envorinment and to } \\
\text { change it }\end{array}$ & $30 \%$ & & & \\
\hline
\end{tabular}


Table 1 illusrates that more than $20 \%$ of second-grade schoolchildren possess the ability to repeat something significant in the form in which it was presented and heard at a sufficient level, $5 \%$ demonstrated a high level. The important qualities of critical thinking are the abilities to express ideas in children's own words or using some other method.

Discussion. We, in our work, adhere to the S. Terno's approach. He believed that critical thinking was an individual's ability to use certain information processing techniques to produce the desired outcome (Terno, 2011). He believes that critical thinking includes the following abilities:

1) to make logical consequences;

2) to make grounded decisions;

3) to give an evaluation (of positive and negative features) of both information and thinking process;

4) result orientation.

Critical thinking development is a system of activities which is grounded on the study of problems and situations based on independent choice, evaluation and determination of the extent of information usefulness for personal needs and purposes. Critical thinking is a rather difficult process of creative processing of information, connected to its realization and rethinking (Lindsay, Hull \& Thompson).

M. Lipman distinguishes 6 key elements of critical thinking:

1) the ability to think, which involves mastering certain techniques that develop the apparatus of thinking operations;

2) independent judgments formulation, which involves the ability to productively compare different judgments and identify alternatives;

3) responsibility, which implies the ability to prove one's own ideas using persuasive arguments;

4) self-correction, which involves a person's use of critical thinking as a method that addresses his or her own judgments in order to correct or improve them;

5) the selection of criteria that a critically-minded person takes into account in order to analyze them in detail or criticize; 
6) attention and sensitivity to the context implies understanding the general criteria in relation to the context of their use and the development of other alternative criteria that are appropriate for a specific situation.

There is a great number of research works, the authors of which, to one degree or another, substantiate the importance and identify the possibilities for the development of particular aspect areas of critical thinking, even in primary school.

Special features of primary schoolchildren's critical thinking are:

- independence of thinking;

- relative independence of thoughts;

- resistance to suggestions of thoughts, patterns of behavior, demands of others;

- critical attitude towards oneself, identification of one's own mistakes and normal attitude to them;

- the search orientation of thinking, the desire to find better options of dealing with educational tasks;

- the ability to participate in a dialogical interaction.

The experiment shows that $25 \%$ of children have a sufficient level of ability to present ideas in their own words or using some other method. No one showed a high level. Only $10 \%$ of students demonstrated a sufficient level of abilities to combine several ideas into one.

Table 2

The results of performing tasks using LEGO construction sets (\%)

\begin{tabular}{|l|c|c|c|c|}
\hline \multirow{2}{*}{ Task Features } & \multicolumn{4}{|c|}{ Levels of Task Achievement } \\
\cline { 2 - 5 } & Beginners & $\begin{array}{c}\text { Intermediate } \\
\text { level }\end{array}$ & $\begin{array}{c}\text { Sufficient } \\
\text { level }\end{array}$ & $\begin{array}{c}\text { High } \\
\text { level }\end{array}$ \\
\hline $\begin{array}{l}\text { "Forecasting by } \\
\text { Illustration" }\end{array}$ & $25 \%$ & $45 \%$ & $25 \%$ & $5 \%$ \\
\hline $\begin{array}{l}\text { "An Illustration Made } \\
\text { after Receiving } \\
\text { Information" or "Live } \\
\text { Drawings" }\end{array}$ & $30 \%$ & $45 \%$ & $25 \%$ & - \\
\hline $\begin{array}{l}\text { "Creating a Story } \\
\text { Using Keywords" }\end{array}$ & $20 \%$ & $45 \%$ & $30 \%$ & $5 \%$ \\
\hline
\end{tabular}


According to the results of Table 2, the analysis of secondgraders' task performance makes it possible to draw a conclusion about different levels of primary schoolchildren's critical thinking development. The task "An Illustration Made after Receiving Information" or "Live Drawings" turned out to be difficult, but it does not only require learning facts or other people's thoughts, but also the ability to see the possibility of applying a particular idea to another situation.

Conclusions. School practice requires the development of new technologies for students' critical thinking formation in the process of learning, using a variety of pedagogical techniques, which encourage students' creativity and create conditions for understanding educational material, generalizing the obtained knowledge.

The development of critical thinking is a multifaceted, systematic and long-lasting process. It involves schoolchildren's directed, organized and gradual mental activity under a teacher's guidance. We believe that tasks with LEGO constructions sets should be used in working with primary schoolchildren to develop critical thinking.

\section{References}

Cluster, D. (2001). What is Critical Thinking? International journal about thinking development through reading and writing, Peremena, 4, P. 15-18.

Facione, P. (1990). Critical Thinking: A Statement of Expert Consensus for Purposes of Educational Assessment and Instruction. Research Findings and Recommendations. American Philosophical Association, Newark. California State University, Fullerton

Lindsay G., Hull K.S., Thompson R.F. Creative and Critical Thinking. Retrieved from http://www.tsure.ru /University/Faculties/Fib/PiBG/creative.html

Terno, S. (2011). Teoriya rozvytku krytychnoho myslennya (na prykladi navchannya istoriyi) [The Theory of Critical Thinking Development (on the example of teaching history)]. Zaporizhzhia: Zaporizhzhya National University [in Ukrainian].

Оригінальний рукопис отриманий 14 травня 2019 року

Стаття прийнята до друку 28 травня 2019 року 